\title{
The Profession AND the TeACHING OF THE LAW
}

\author{
R O McGechan*
}

The following paper was given by Professor McGechan to the Dominion Law Conference held in April 1947.

I welcome the opportunity your committee have so kindly given me to bring before you some of the really pressing problems of legal education. I may say at once that I appreciate very much the very considerable help the College has had from Wellington practitioners. During the war I found myself the only full-time Law teacher left at Victoria University College, and I am, and the College is, sincerely grateful for the work done during those years by our team of practitioner lecturers, who included, incidentally, two Presidents of the District Society. That help was given at a time when all were trying to get the better of heavy practice and short-staffed offices. I have paid tribute before to this-and to the spirit in which it was done-but let me pay it again in this our first post-war legal convention.

We lawyers have a vital interest in legal education. We hold a privileged position in the community, and we must be worthy of our privilege. That involves much else, but for my present purposes it means that we must be a well trained and well educated profession. Pride, just pride, in our profession and its achievements over the centuries demands that we be as well trained and educated a profession as we can possibly be. I am sure that all of you to-day will agree with this.

There are, no doubt, other factors contributing to a high standard of education and training in our profession, but for the present let me concentrate on the three phases which are of current interest to both profession and teachers-(i) length of the law courses, (ii) examinations, and (iii) teaching methods. All of these bear on our standards.

* Professor and Dean of Law, Victoria University College. The paper and comments following it were first published at [1947] NZL] 110. 


\section{LENGTH OF LAW COURSES}

There is still a minority, pretty persistent, which looks back to the good old two-year course as to a golden age. I have tried to analyse the reason for this persistence, and, so far as I can see, its bases are three. First, and the strongest really, there is the persistence of good old pioneering traditions; secondly, there is the fear that a long course will deprive the profession of numbers necessary to carry it on; thirdly, coming from some of our country practitioners, there is the fear that a long course takes clerks away from the country. Let us have a look at each of these.

\section{A Pioneering Traditions}

A pioneering country has no great use for experts or highly skilled persons. A successful pioneer is one who can turn his hand to anything. If, then, a person has ability, best let him turn his hand to whatever and as many things as he will. A pioneering community has no use for, in fact, cannot afford to have, high qualifying standards, even for professional life. At first we built up our profession in New Zealand on these assumptions. But in due course of time we ceased to be a pioneering community, and we can no longer go on assuming that native ability alone, without proper training is enough. A developed society looks more and more to the skilled person, and it will demand more and more skill. And, as you only too well know, civil servants and accountants and others have acquired skills in branches of work normally done by lawyers. So that the unlimited opportunities we had in pioneering days have given way to the need to hold our own against trained and skilled competitors. Naked ability has not for some time been, and never again will be, enough.

Do not forget that civil servants and accountants are at this very time pressing for higher academic qualifications. And, if we glance at our own profession abroad, we find that this year, as an alternative to a four-year University degree course, the Victorian solicitors have induced Melbourne University to introduce, not a shorter but a longer course, a five-year University course. Surely this from competitors here and from practitioners abroad should induce extreme caution toward persistence in demands to reduce qualifications in New Zealand.

\section{B Deprivation Of Necessary Numbers}

The second reason behind advocacy of lower standards is the fear that a long course will deprive the profession of the number necessary to carry it on.

But the present state of our classes in law shows conclusively that the five-year course is not depriving the profession of the necessary numbers. Law got more than its fair share of the record numbers attending the Colleges last year. The extent of the increase is not as widely known as it should be. My class in Roman Law jumped from under thirty in 1945 to over seventy in 1946. This class was a fair sample. The increase was not solely due to 
returned servicemen. Numbers in law had been rising for three years, and rose in 1946 quite apart from returned men. They increased, but did not create, the boom in law; apart from returned men, the Law Faculty at Victoria has more than doubled its numbers since I came in 1940. I was amused to find, after years of complaint at the shortage of clerks, that, when I told a group of practitioners in March last year of the increased numbers, they immediately wanted to know what on earth they were going to do with them. We do not need a shorter course to keep up our numbers.

That numbers did decline in the thirties is true. Some of you argued that this was the result of the longer course introduced in 1938. The argument was never sound. Numbers fell off before that course was introduced, and they did so because of the depression which in the early thirties hit very hard a profession then very overcrowded. How could you expect boys leaving school to go in for law, whether it was a two-year course or a five-year course, when every practitioner they met told them there was nothing in the game for anyone?

Numbers going in for law have increased because the impression has once again got about that it is worth while going in for law, and a steady rate of recruitment seems assured. I have seen a few striking instances of the renewed interest in law. Among new students last year was a fully qualified architect who preferred to switch over to law, even though he was refused a rehabilitation bursary. One civil servant at least chose to quit the service and take a job at a financial loss as a law clerk rather than take preferment involving transfer away from the city where he wanted to finish his course. And I can assure you, moreover, that the percentage of civil servants in our classes has fallen with the rise in student numbers. The increased numbers will very largely go into the ranks of the profession.

\section{Country Clerks}

The third argument against a high standard of legal education is a peculiarly country one. The country practitioner often argues that, if there were only a short alternative course, clerks would stay in the country and take it there. But I am quite sure there would be no appreciable increase in country students if the course were shortened. It is not the length of the course which brings law clerks to the city. Country practitioners tend to forget the blandishments of the city.

To begin with, it is Government policy that as many as possible shall come to the University. In most cases the Government pays their fees. It grants more and more liberal boarding-allowances to more and more bursars. We are in fact a good deal nearer free University education for all than most people imagine. And, strangely enough, most parents seem reluctant to throw away this something for nothing the Government dispenses.

But whether there were bursaries or not, and even if there were a short course, law students would still flock to the city. If you look abroad, you will find that law faculties 
often compete with non-university courses, and always the universities increase their numbers of law students at the expense of alternative qualifications. I have read of this trend in England and seen it happen in New South Wales. A student will always prefer the tuition of a University to doing it on his own. A short course would be taken in the city rather than the country, just as a longer course is.

And do not forget that a clerk will get a wider range of experience in a city office than in a country office. Country practitioners, I find, mostly want their sons to have a few years in a city office.

But in any case I do not think that a shorter course will ever again prove attractive to students. I have watched the student body as student and teacher from depression days onwards, and one change in its outlook, directly traceable to the depression, is apt to escape the attention of those who reached maturity in pre-depression days. There was a time when good livings were to be had for the asking. Any qualification then satisfied a clerk. But since 1930 good livings have not been so easily come by. The student tends to want the best qualification, the best preparation for professional life, he can get. Otherwise, he fears he will just not be in the race. He will not from choice take a solicitor's course when there is a higher qualification available. I am inclined to think that it would be only those who failed too often who would take refuge in shorter courses.

There are no good reasons, then, for reducing the length of the law course, degree or solicitors. Reduction in the length of the course is one way of reducing our standards. And reduction will not increase the numbers going in for law. Recruitment turns almost entirely on whether youth and their parents think the law worth while, whether they think that you can get a good living out of it. Even if a shorter course did induce more to enter the profession, this in turn would soon lead to overcrowding, and the results would be an overcrowded profession, with a low standard of remuneration and a low standard of education, a state of affairs we do not want.

\section{EXAMINING}

I cannot help thinking that those practitioners who constantly press for shorter courses imply in so doing a criticism of University education in law. It is a pity the criticism is implied and not overt, and I am going to bring it out in the open if I can. Radical changes are taking place in the University, and the time is appropriate for such criticism.

I have been told quite good naturedly but quite bluntly that some of those who took the old seven-unit course have become very successful practitioners. Of course they have. I am not so frequently told, but I know, that some of those who took good degrees have become very successful practitioners. The explanation is that people who have ability tend to be successful. But it is none the less true that those who took the seven-unit course and have succeeded would have been better equipped, and probably even more successful, if they had 
had a fuller training in the first place. Quite a few of them know and admit this. And it is also true that those who took good degrees at the University and succeeded would also have been better equipped, and perhaps more successful, if their University training had been better. And the same applies to those who take degrees hereafter. We cannot, of course, test the efficacy of a system of training by appealing to the success of A, B, C, or D. And success of those who had no training, or did not have the best possible training, can be neither justification nor excuse for not giving everyone entering the profession the best training he can be given in five years. For this reason, I want to see University institutions so framed that better training is possible. I am not satisfied with the present set-up, and I hope that what follows may persuade you to assist the teachers in securing some long overdue changes. My present purpose then, is to show you that legal education is not even now as good as it could and should be, principally because the teachers have never had the opportunity to do all they could to improve it.

We are especially conscious of the hampering set-up at Victoria University College, where we have, as you know, to some extent specialized in law. We spend a good deal more money on the Law Faculty than any other College does. We are more fully staffed. With two Professors, two Senior Lecturers, and part-time Lecturers in Procedure and Conveyancing, and further assistance to mark opinions set our students, we are of course not perfectly, but still we are not unreasonably, staffed. We have a very good law library. We have more students in law. And the Faculty gets, I think more sympathetic consideration from Professorial Board and College Council than do the Faculties in other Colleges. We could do much to improve legal education. But we are forced at present to move in step with three other Colleges. Now, we have, and each of the other Colleges has, its own individual approach to the teaching of law: independent, each might get somewhere; together, we straight-jacket each other. The crying need of the Law Faculties, as of the University Colleges themselves, is to be free of each other, so that each can develop. The straight-jacket cracks the bones in examining. There can be no real progress while one examination paper is set for all four colleges, and there will be less progress than there should be while the teacher is not given at least equal status with the practitioner-examiner in setting and marking papers, as he now has in medicine.

In our endeavour to secure changes in the present examining system we have met opposition. I think the opposition is based on certain misconceptions, and, if pursued, will do no one any good. So I want to devote some time to examinations in law.

I do not think all practitioners are aware of the present position, and I had better state it briefly. Like all other New Zealand examining, law examining was originally external. External examining had two features-first, it imposed one common paper on four law faculties; and second, it kept the teacher and examiner at arm's length, denying the teacher any responsibility. 
The theory of external examining was that a common paper lifted the worst college to the standard of the best. And the theory of English external examiners - an integral part of the early system - was that Englishmen would somehow maintain high standards. But teachers for thirty years have known that this system only debased and lowered our standards. The common paper brought the best down and did not lift the worst. All that has been achieved has been a dull mediocrity. The English examiner, in the biting phrase of Professor Gordon, "achieved a high level of examination papers." In Law, our examiners did not even achieve a high level of examination papers.

The position in Law was modified to some extent in 1941. Teachers were given the right to submit questions to external examiners, who would then draw up a draft paper, which might or might not adopt our questions, and circulate it among the teachers. These in turn would have the right to comment on the draft. With these comments before him, the external examiner finalised the paper. His was, you see, the whole responsibility. And the core of the evil, the common paper, remained. As to marking the scripts, we were given the right to do what is called preliminary marking i.e., we could assess the value of answers of our students, putting the marks on the paper, but leaving it to the external examiner to use or ignore our work as he pleased. Again, no responsibility was placed on the teacher.

The scheme mitigated the evils of external examining to some extent, but it has not freed us from them. You may submit questions, but they must still be questions suitable to four centres. So that the curse of dull mediocrity is still very much with us. In fact, the common paper is really only another species of external examining.

The results of external examining on University education-including legal education-need further elaboration, for I want you to understand why, in our eyes, the system stands condemned.

The effect on the student first. The student knows that his own teacher will not set the paper, someone else will. What will that someone else set? There is no certainty that the paper will ask questions about the things he has been taught to regard as important. The examination, to the student, therefore, is a gamble. The best bet is to concentrate on a range of obvious questions. And, taking it by and large, the student who does this does well. I can see no good reason for rewarding such a student. I have been told by one law examiner who worked under the old external system that within a few years he found that he had to repeat questions he had already set. You see, obvious questions soon run out. Now, clearly, you cannot keep any sort of standard, you cannot induce students to learn a subject soundly or fully, if students once find that they need only learn those portions of a subject already set. Today we have grown skilful at avoiding the semblance of repetition, but it is still very much with us. 
Just as serious is the fix you place a good student in by giving him divided loyalties. He wants to do well in his examination, he wants to get the best he can out of his teacher. $\mathrm{He}$ cannot do both. If he gets the best training his University teaching can give him, he will get no extra marks for it in his examination results, probably he will get less, for he will not have parroted off the answers to certain questions so well. External examinations do offer rewards to a low standard of study.

The trouble is that the external examiner cannot lift himself out of this comparatively narrow range of questions. He does not know what is being taught; if he sets obvious questions, he will keep safely within the limits of what has been taught in all centres. $\mathrm{He}$ can, of course, subtly vary the obvious, but he cannot get away from it without producing extraordinary results, for, if he sets a series of questions on obscure points, he will only substitute a lottery for a poor paper. Of course we have had our lottery papers. One year, the examiner in Constitutional History (then purely external) set a question or two on the New Zealand Constitution. But no one here then thought this worth the student's attention. The examiner no doubt found that he had either to fail everybody or pass everybody. Pro tanto, he had not set an examination paper at all, for it did not separate the sheep from the goats. And, of course, different people take different views of what is important in any subject. There is no one-and-only approach. An external examiner is certain to miss some of the things a teacher regards as important, and which, in fairness to a student, should be reflected in a paper. And, unless he keeps to the obvious, the opposite will happen-he will put in things he regards as important, but which the teacher has not so regarded.

Neither an obvious paper, nor a lottery, nor the obvious with a dash of lottery, nor a lottery watered down by the obvious, will provide a proper atmosphere for students to work in. Their standard of work was, and still is, lower than it should be in consequence.

The teacher is the only person who can really set a paper to test a student's knowledge, intelligence, aptitude for the law, industry, and reading in the subject. He alone, in the nature of things, can know when a paper is too poor to test and when it is too much of a lottery to test. This need-the need to associate law teachers in the setting of papers-as you will have seen, was acknowledged in the compromise examining scheme of 1941 we now work under. The lottery, it is true, has almost entirely disappeared under the present scheme, but the common paper still means a low standard, because the questions must still be suitable to four Colleges, and that which all four regard as of some importance does not reach the level of work of any one college. So we have not yet gone far enough in eradicating the defects of the old system.

What of the effects of external examining on teachers? Well, there are ludicrous tales told of the genius for tipping questions shown in the old days by some professors. As teachers now in fact know the paper set, tipping would be a gross breach of confidence, and I presume that we have put an end to that in law examining for LL.B. But the worst evil 
resulting from external examining was the constant trend to coaching. A university is not a coaching college, not an institution designed and operating to get people through exams. It is an institution to teach people, to impart knowledge. If you really want to bait me, to make me see red, you have only to suggest that I am even remotely interested in pushing Johnnie Dullard, who has not the ability to practise law, through his exams. My teaching will not be devoted for a single instant to getting students extra marks in examinations. In other words, I will not coach. My task as a teacher is to teach my subjects to my students to the best of my ability and to the best of their ability. But I do need, for the sake of my teaching and their learning, an examination system which encourages teaching and not coaching. What I have said goes for all law teachers at Victoria University College. The compromise of 1941, I fear, has not put an end to coaching.

The real interest of the legal profession in University education in law is surely to get good teaching. But at least the representatives of the profession, I fear, have clung to an institutional set-up which encourages poor teaching. This was forcibly brought home to me at one meeting of the Council of Legal Education. I found that the prescriptions in no less than four LL.M. subjects required students to study English and not New Zealand law. In moving to change it, I naturally did not expect opposition from the profession's representatives, from a profession self-advertised as hard-headed and practical, and this change surely would have made our work of more practical value. The change was opposed, however, by your representative because English examiners could not so conveniently examine New Zealand law. The opposition was just fantastic. Fortunately, the Judges were more practical. But you see just where faith in external examining sometimes leads you.

We have not had to go so far as to teach English law so that the standard of our New Zealand degree could be adequately maintained by English examiners, but teaching has been influenced by the known or assumed limitations of our examiners.

Let us take the teaching of the law of real property in New Zealand. For a generation this has been based on Garrow on Real Property. I pay all due respects to Professor Garrow as a pioneer in the field, but the plain fact is that students, particularly good students, cannot understand Garrow on Real Property. The reasons are clear enough, the book is not one which lays any clear foundations on which to build a knowledge of real property. Then, even as clerks, our students learn that the Land Transfer system is important, and must have difficulty in squaring their discovery with the cunning way in which the importance of that system is camouflaged in Garrow. We know that real-property teaching needs to be completely recast. We mean to do something about it at Victoria University College. This reform, I suggest, would have occurred years ago had it not been for the fact that practitioner-examiners have examined by the light of Garrow. I am by no means confident that practitioner-examiners will not go on doing so. Moreover, if we are to continue to have a common paper, I do not see how a fair paper can be set to test the new 
teaching and the old, for I do not suppose Garrow will be abandoned in all four Colleges. I fear that our students, though better grounded, and possessing a fund of more practical knowledge, arranged in a more practical manner, will not get the marks they should get in examinations. What do you want? Do you want Property well taught, or do you want to dominate University examining ? You cannot have both. Which is the more important? I may add here that we have had far too much examining by the dim light of out-of-date text-books, and of text-books which are just poor.

In terms of educational efficiency, I would liken our position, with its common examination paper, to a kind of five-legged race. You cannot tie the legs of your team of four sprinters together and expect them to travel as far and as fast as even the slowest of them.

It is against this background that the full-time teachers have pressed for certain changes in law examining. The proposals aim at two things, (i) separate papers for the four Colleges, and (ii) equality of status for teacher and practitioner as examiners In each subject there would be two examiners for each College, the teacher and an external examiner. In the subjects of Divisions II and III-the so-called "practical" subjects-the external examiner would be a practitioner. And we would have one practitioner only for all four Colleges. It would be the task of that practitioner to see that any papers set did not fall below a level he thought necessary to qualify for practice. He could see that the papers did not become too hopelessly impractical; they will not, but there is no harm in expecting him to do this. The marking should, we think, be left primarily to the teacher, with the practitioner acting as a check-examiner. I have always found that examiners do not differ about obvious passes and obvious failures, it is only as to a few papers on the border-line that there is difference of opinion. I cannot see any use in requiring a practitioner-examiner to re-mark laboriously every single script. His function should be to take the border-line cases and check-mark these. He should, of course, have the right to mark any script, and he should compare the level of pass and failure of each college and endeavour to equalise these levels. The equalising cannot reach a fine degree of accuracy, but, as we shall see, the common paper's common standard is apparent only.

Neither internal nor external examiner, teacher nor practitioner, should be subordinated to the other. I do not want as a teacher to be able to override an external examiner; but I do not think he should be able to override me Where we differ, we should discuss our differences. I have had enough experience to know that, after discussion, most examiners can agree, and reasonable men can compromise if they cannot agree. But there may be cases of pigheadedness of teacher or practitioner, and I think the best way to get over this is to provide that the decision then go to a third person, a practitioner for the subjects of Divisions II and III. The mere fact that a man may have ultimately to justify his judgment to another will induce reasonableness in the first place. Provision for reference to a third party will make any reference largely unnecessary. 
What is the objection to separate papers in Law subjects? The change is certain to raise the standard of work in every college adopting it. The examination would thereafter be a reflection of the teaching, and students could follow our lead without one eye cocked on an inferior examination paper. Why, then, is the change opposed?

It is no use arguing that the change would create different standards in different colleges. To begin with, these different standards already exist. We teach our subjects differently because we cannot help it; some colleges teach more effectively, I suppose, in one subject, others in another; library facilities differ; text-books differ. There is no uniformity now. And a common paper does not secure uniformity of standard. The problem is not so simple as some practitioners suppose. Let me give you one simple illustration.

Let us suppose a question is framed according to the phraseology of Salmond and Williams on Contract, and suppose that of two students of equal ability, and equally well prepared for an examination in Contracts, one has been trained according to Salmond and Williams, the other on Anson. They will not gain equal marks for that question, and yet they should. This problem is not imaginary, even though practitioner-examiners have some of them not noticed it, and others have ignored it. Every question set has advantages to some College and disadvantages to another. The University, for this very reason, had to abandon the common paper for Medical Intermediate as a means of selecting students from the four colleges to enter the Medical School. Reason, evidence, and the precedents are all against you if you go on asserting that at present we have a common standard to determine pass or failure in law.

At the present time, our standards have about the uniformity of Brown's cows. One year $X$ examines in the $A$ subject and passes thirty per cent. The next year $Y$ examines in that subject and passes eighty per cent. The standard in some subjects is too exacting and in others is too low. I remember a case during the War where a teacher who, as it happened, was also the external examiner in another subject marked two papers for a student and placed him in the seventies, regarding him as of equal merit in each paper; one external examiner put him high in the eighties, so that he now regards himself as therein akin to genius, and the other put him in the low sixties. You know what I mean by a legal fiction: the uniform standard is a University fiction. And I do not think we should have this chaos.

I have heard a fear expressed in some quarters that, if teachers examined, they would pass everyone; and I have heard the exact opposite, that they would fail everyone. Why a teacher should want to pass everyone in an examination he sets I cannot fathom; he could only thereby demonstrate his own lack of judgment. The fear that he might fail everyone I would dismiss out of hand as without substance did I not perceive in it a fear that our undoubted desire to raise standards would mean more failures and threaten the recruitment of the profession. But I have no intention of failing more and thereby deluding myself and others that the standard has been raised. Standards depend primarily on teaching. If you 
pass the same number and those who pass have been better taught, your standard will really have been raised. You can go on failing large numbers without really raising the standard at all. Some practitioner-examiners have been under the illusion that they have been keeping the standard up. In any case, we contemplate a check-examiner, who in the practical subjects will be a practitioner, and he can be your watchdog in this.

I cannot help thinking that part of the objection latent in opposition shown to our proposals comes from a fear that we teachers are not practical, and cannot be trusted to examine students qualifying for a practical profession. So far as I am concerned, I think you should realise that I spent three years in a solicitor's office as an articled clerk, and practised for nine years at the New South Wales Bar before turning Professor. I have not discerned that what was practical in New South Wales differs from what is practical in New Zealand. And New Zealand practitioners always seem to me to infer that Australian practitioners are not soft-headed. How, then, can you suggest that I do not know, when I teach, what will prove useful to a student in after life? And why should I want to produce someone who is erudite but unfitted for practice? On the contrary, I am well aware that we must at present produce graduates who can immediately step into court work and office practice which formerly were entrusted to men many years their senior. That our young graduates have handled their work competently-and I have had many good reports of itgoes surely a long way to prove that we are producing sound practical lawyers.

I am puzzled to know what practitioners mean when they suggest that our teaching is not "practical". The only intelligible meaning I can give the word in this context is "that which may be of use in practising law." But, if this be its meaning, there is precious little which is impractical, for law has an uncanny habit of stretching into highways and byways. Take any volume of Reports and see just what stray bits of legal learning have achieved that most practical of all ends, a case won for a client. Cases are sometimes won by citing Justinian's Institutes, Holdsworth's History is cited more and more, and I found a practitioner recently who maintained that the First Edition of Jarman on Wills was a great case-winner. There is extremely little we raise, or want to raise, in our lectures which may not be of some use to someone in practice; on the contrary, I would class a good deal of casewinning material as too far away in the clouds for my students.

Now, obviously in teaching we have to make a selection. Students cannot be taught all the law in five years; nor, in one year's study of any subject, can the student be expected to master the law on that subject. But our problems of teaching cannot be solved by selecting those parts of a subject which will obviously be used in practice. The problem is not so simple. A teacher can and will use a good deal of such material, but of course he is introducing the subject to someone who as yet knows nothing about it, so that a teacher must concentrate on giving his students a foundation on which to build later a practical fund of experience. Teaching, in fact, is the making of the foundations of knowledge to be acquired 
afterwards. If a teacher ignores the foundations and plunges into practical problems, the result will be, for all but the very ablest students, chaos, and chaos lasting for years after student-days are over.

This all bears on the problem of examining. Is the student to be taught the foundations and yet examined on something else? The theory of practitioner-examiners is that they ensure that the paper set is practical and is marked accordingly. If this theory were translated into actuality, the result would be very unjust to the student. The unfairness would probably not arise so much from his not knowing these things; we introduce him to most of them. The unfairness comes from what the paper omits rather than from what it includes. The paper would not be directed to testing his basic knowledge of the subject. And, after a few years of such papers, students would ignore fundamentals and learn to get through on a few isolated and non-coherent scraps of knowledge which they have discovered to be the only material covered in the examination papers and which have come by convention to be regarded as practical questions. Teaching is frustrated as soon as that happens.

The theory of a practitioner-examiner is that he will ensure that the paper set is practical, but mostly he has not done this. The best practitioner-examiners have come from those who have taught in the colleges, and have therefore had practical teaching experience and some knowledge of what a student should be expected to know. Others have soon found themselves forced to confine their papers to a range of obvious questions which kept the standard of both examination and student work below what it ever need have been. Practitioner-examiners have never served the purpose for which they were appointed, and which no doubt many of you are under the illusion that they have served. When, before 1941, they had not the assistance of draft questions from the teachers practitionerexaminers seem always to have felt that they were working in the dark, and so played safe. Since they have had our draft questions, they have felt happier and shown their appreciation of the need to correlate teaching and examining by nearly always adopting our questions.

Much of what I have said applies equally to marking scripts as to setting papers. If you mark to ascertain whether basic knowledge has been acquired, you may get one result; if you mark to see how much practical knowledge has been acquired, you may get another. Where we teachers have done preliminary marking, discrepancies of this type have been infrequent. But, where we have not done this, there have been cases where students have been given first-class terms by the teacher, in recognition of work well done throughout the year, but in their final examination, marked by a practitioner alone, have just scraped through, even in one or two cases failed; and, worse perhaps, there have been cases of some who have not done the work necessary to equip them for later expanding their knowledge, but have been regarded as geniuses by practitioner-examiners. Discrepancies such as these do not serve the 
cause of legal education. Students who feel that they may be the victims of this sort of thing cannot be taught; they will fiddle about with examination papers rather than work at the subject. I have said that these cases have been infrequent, but their demoralising effect among students is out of all proportion to their number.

In estimating the value of practitioner-examiners as an assurance of practical examining you must also remember that ripe practical experience is its sine qua non. Unfortunately, however, ripe practical experience goes with a practice which leaves no time to the practitioner to act as an examiner; For its practitioner examiners the University is forced more and mote to turn to younger practitioners. Obviously the practical contribution of younger practitioners must be less. They may, of course, be better examiners, but they will not serve the purpose practitioner-examiners are supposed to serve.

Through inexperience as examiners, I think, practitioner-examiners have quite often failed to check a student's knowledge of the most practical parts of a subject. One prominent in law in the city told me that in the good old days he passed in Property without knowing of the Land Transfer Act. So much for the reality as opposed to the theory of practitionerexaminers. No teacher who examined would allow that to happen.

Lest I be misunderstood, my objection is not to practitioners working with teachers as a team of examiners, in partnership. My objection is to a set-up which places responsibility on the practitioner to the exclusion of the teacher.

\section{TEACHING AND TEACHING METHODS}

I have always thought that the call of practitioners for practical teaching has been directed to the wrong aspect of teaching. The demand has been that the matter of our teaching be practical. It is, I think, much more important that the manner of our teaching should be practical.

Learning the subject-matter of law by rote will not make lawyers. One incident of a few years ago brought this to my attention. One practitioner-examiner talked over teacher-examiner problems with one of our part-time wartime lecturers and advised him that, if he wanted his students to do well, he should set them a ten-minute test on their work, I think every week, just, I suppose, to see whether they knew it. ${ }^{1}$ I refused to allow the

1 I have since been informed that the purpose underlying the suggestion made by the examiner was to improve the accuracy of expression of candidates. I appreciate that this purpose is a sound one, and am glad that I was unduly pessimistic in the view I took I still think, however, that the results of the method proposed would do little to improve accuracy of expression and would have all the objectionable features indicated above. 
teacher to teach by this method. I believe that this is a hopeless method of teaching a man to become a lawyer. But notice, before I go on, just how examining may interfere with teaching. No doubt, if that teacher had proceeded by that method, more of his students would have got through, and most of them would have got higher marks. But I am not chasing examination marks. I teach to make lawyers, not examinees.

If you pick up any cram text-book in law, you will see the wrong method of teaching reduced to a fine art. They are ideal books to prepare you to pass ten-minute tests of what you know. They set out in dogmatic form the cardinal principles of law, each followed by an example to show you what is meant. The student has only to learn that there are ten points under a certain heading, and, to prove conclusively that he really understands the matter, reproduce the examples set out in the book, with the names of cases if he has a good memory, and, if he wants to dazzle an examiner, add the references for good measure. But you can acquire a lot of law in this way and get thrashed by the Bench every time you go into Court. Of course it is no use going into Court and dogmatically stating a principle of law culled from a cram text-book and adding an illustration. The authorities for any proposition are wanted, and the illustration the student has learnt off has a habit of not being apt to the matter before the Court. If you are to train a student to handle his knowledge in a professional manner, you must show him how to derive principles from cases. You must carefully, consistently, persistently teach from the authorities to the principles. To send a student to a text-book and let him assume it is the answer to his problems, that it is authoritative, that he can qualify for practice by learning it, is, I think, wrong. Dogmatically to assert principles of law in lectures is no better. Students must be taught to go to the cases and the statutes and to derive their law from them. This is our aim at Victoria University College. I dare not pretend that we have mastered its application to New Zealand conditions. We have sought to lecture in this way, we have given our students written opinions to work out for themselves and often had them marked by practitioners. I myself am experimenting with moots here and there through a course, instead of lectures. For the student, this may mean learning the hard way; for the teacher, it means teaching the hard way. But I am satisfied that it is well worth the effort. In any event, I want you to know and appreciate what we are doing, or at least trying to do.

We are not helped in the endeavour to teach in this way by a common examination paper for four Colleges. Students taught in this way need an examination paper framed to encourage them to learn this way. What we have at present is an examination paper which, because it seeks to be fair to four Colleges pursuing four ways, tests neither competence to practice, knowledge of the subject, intelligence, nor ability in the law-an examination paper dedicated to mediocrity. Is uniformity through mediocrity to be our aim?

I hope you will not regard us teachers as outside the profession with separate interests and an alien outlook. We are part of the profession, sharing its ideals and conscious of its 
difficulties. We are that part of the profession charged with the training of new entrants. Let us take responsibility up to the hilt for this work. The profession needs the best it can get out of us. And you always get the best out of a man when you place responsibility square on his shoulders. Hedge us round with all sorts of limitations and the profession is the loser. Like all of you, we want to play our part in building a healthy profession: we will neither pitch our standards so high that the profession dies out, nor so low that it falls into disrepute: we want, as you want, the healthy medium. But we can raise our standards without lowering our numbers. Surely you can help to free us to do this.

The following discussion then took place.

MR. K. M. GRESSON (Christchurch):

"Not a little of Professor McGechan's idealistic paper is controversial, and I must go on record as dissenting from some portions of it. He dealt with the question under three heads (length, examination, and teaching methods), and I will content myself with saying a few words on each, so that I clear myself of assenting to some of the propositions. First, as regards length: I do not think any one would question that to-day there is so much law to know, and to be an efficient lawyer calls for so much, that the course must be reasonably long, but not all of that is spent learning law. When the course was lengthened some years ago, it was done by including B.A. subjects, so that now the student has to do five-ninths B.A. The theory was that it would give a cultural background. The theory is all right. In practice, it is quite otherwise, because the student does not select subjects of the greatest cultural value, like History, English, Greek Literature, and so on; he selects Logic, Psychology, and Political Science - frankly because these subjects can be "mugged up" easily. I do not say that those subjects have not any value, but they do not supply the wider cultural background that it was thought would be secured by making the students take five-ninths B.A. Furthermore, it is open to question whether the effort and the time spent in taking Roman Law are worth while. I, at any rate, would make it an optional subject. Professor McGechan deals mostly with the question of examinations, and has developed at considerable length his views on that topic. That is so big a question that we cannot discuss it here and now. I content myself with saying that I do not subscribe to the view that there is a crying need to be free of the examiner. I do not think that the core of the evil is the comman paper. I do not think it is a bad thing. It is inevitable that there should be some repetition of questions. After all, the standard is that those who pass out to serve the public shall be reasonably well-equipped, and at least the alterations made of late years have enabled those engaged in teaching to see the proposed questions set by a man in practice, and to object to them if they wish. Questions are often dropped because of objections from the teachers, and that brings the teacher, in my opinion, into sufficient contact with the examiner. And, on purely personal grounds, I flatly refuse to examine sons of my clients, of fellowpractitioners, sons of my friends; and for other reasons, I am just not going to do it. I 
think that view is held at Otago, too. At any rate, the part-time teacher in law is in a somewhat embarrassing position if you ask him to examine the sons of his fellow-practitioners, and his clients' sons. So, from that angle alone, I do not subscribe to Professor McGechan's view that the teacher is the only person who can set a paper, and I do not think teachers should be compelled to examine. I would have liked to have heard the matter of teaching methods developed at considerable length. I think that the teaching methods are bad at present. What do we do, most of us who teach ? We hurry our students, reluctant or not, as the case may be, through great long Acts, and until they have acquired sufficient familiarity with those it is useless to talk about their application. Until you have hammered the sections of Acts such as the Companies Act, and so on, so that they have acquired at least a knowledge of them, it is useless to talk about their application. Why cannot we let students go into the examination room with the Acts, and be examined with the Companies Act, for instance, in front of them-just the Act, not the annotated Act. None of us carries it all in his head. We have some portions of Acts in our heads through a good many years' teaching, but we do not attempt to know them all; they are on our shelves, ready to hand if we want them. What we want to teach is the interpretation of the sections. In the Army, in an examination on Military Law, they go into the examination room with a copy of the King's Regulations. If the student went into the examination room knowing that he would have access to sections, he could be examined on their scope and purpose, instead of having simply to swat to know the sections, as he does at present. Take the Companies Act, with which every one is familiar. It has 300 -odd sections, and at present students have to spend a considerable portion of the year memorising requirements for incorporation, etc., grounds for winding-up, and so on, things which must be included in a prospectus and so forth. In the rush and scramble to-day, and with the amount of study a student has to do, ho cannot do much more than memorise the relative Acts. That is not true, perhaps, in Torts, but there are many subjects dominated by one book, and the teaching reform I have pressed for-and perhaps been laughed at for-is that we should allow the students to go into the examination room with a set of the Acts. This subject is one that I do not think the average legal conference will discuss to any length. My experience over thirty-five years is that the average practitioner is interested in teaching and examinations for only a short period, when his son is just about to enter upon his course; but, once his son is through, he does not care two straws about it."

\section{MR. F. L. G. WEST (Auckland):}

"I agree with Professor McGechan that what is wrong with the profession to-day is that we are not sufficiently interested in the production of our new members. We ought to be grateful to him for coming along to-day from his University to lecture us practitioners. The subject is of really great importance to us. It is not only practitioners who are concerned. From those who pass law examinations come Magistrates and Judges, a large number of Civil Servants, and people who work for trust companies-people with whom we come into 
intimate contact all the time. But it is particularly important to see that our judicial body is properly recruited. I have myself acted as an external examiner at the University for some twenty years, and, when I look around at the "dull mediocrity" which has resulted, I am seriously perturbed. I know that Professor McGechan will take anything I have to say in the right spirit-l am not speaking personally-but I was struck with the repetition of the phrase "dull mediocrity," which it was said resulted from the system of examination at present in existence. I think the danger is that we may change our system to meet the needs of good teachers. We have good teachers. Victoria College has a good one in Professor McGechan. If we change our system to meet the needs of good teachers, we know what the result will be when we have bad teachers - and there are and have been bad teachers-the system will not be adequate to deal with the situation. The same applies in the case of good practitioner-examiners and bad ones. We have had bad examiners-you have had a good one in me, fortunately. I had that subject known as Torts, which does not lend itself to the long enumeration of statutes. But I think the fault goes back some seventeen years in the profession, to the time when it gave up control of the examination for entrance. Until 1930, the position under the old Law Practitioners Act was that Judges were responsible for prescribing the examinations for entrance into the profession. In that year, provision was made- wrongly, I think - by amendment to the Act, for the power to prescribe examinations for the profession to be handed over to the University of New Zealand. That was done for reasons which I need not go into now, but it has resulted in the Senate of the University of New Zealand prescribing the scope and nature of the examinations necessary for entrance into the profession, and the first point I would suggest to you is that we, as a corporate body, should take back that control of entrance into the profession as soon as we can. How we are to do that, I do not know, but we have to watch these trends. I was struck yesterday, in looking at this Conference paper, with how the subjects deal with what are more or less trends rather than actual fact-problems of the abuse of delegated legislation, public policy, and the remits, all deal with trends in the development of the profession in the social life of the country. The University to-day is about 90 per cent State-controlled from a finance point of view. It is possible that some of us may desire the State to control entrance to the profession, but it is - doubtful in my mind whether that is a good thing. Our method of control now is through the outside examiner, and in that respect I have had some experience both of the old system and of the new system established in 1931. I am all for collaboration between the teacher and the profession in every way possible. It is possible that the profession might have a say in the appointment of teachers. If we had that, we would not be in the same difficulty. We have no such say at the present time; they are appointed by the Colleges. Luckily, the Senate in past years has been dominated to some extent by lawyers-as Chancellors and in other positions. If we had a say in the appointment of teachers, then in this system of accrediting, by which the teacher examines his own students, I think the position of the external examiner in the scheme developed by Professor 
McGechan would be little more than a sinecure; as he says, the examination of the few odd ones on the borderline might be reviewed, but the rest the external examiner would not be concerned with. If we are not to have a say in the appointment of the teachers, then our only hold over the system is to have some control over the examination for entrance to the profession. We as a profession, I take it, have nothing to say-we are not entitled to speak-as to the University position. The matter of the four Colleges being separated to the extent of having their own examiners is a matter for the University. If the University of New Zealand is not to control the matter, then there will have to be a degree for each separate College, and the profession ought to be able to say-the Council for Legal Education, or the Judges-that they recognise a degree given by one of the separate Colleges as a sufficient examination for entrance into the profession. I do not agree at all with the present system. Teachers are entitled to send draft questions to the examiner, who can adopt them or otherwise; or the examiner can set his own paper, and send it to the four heads of the Faculties and receive their comments on it. That has to take place, under the University procedure, about June or July in each year. I make no reflection on any teacher when I say that it is practically impossible for a teacher who has the paper that is to be set for the examination in November not to devote, perhaps unconsciously, a little extra attention to branches of the subject which he knows are the subject of the examination paper. He would not do it deliberately, but it seems to me, in view of that, that it is unwise to have the papers circulated to all Colleges, perhaps have a revision typed by a confidential typist, and have it shown to the lecturers in June or July of each year. It is a bad principle to allow the teacher to know what is going to be set for the examination. My second point is the question of teachers themselves - whether their method of teaching in any particular case is the right one or not. I do not want to touch on that to any extent. Personally, I am in agreement with Professor McGechan that the students want to know the fundamentals, on which they can build experience. If Professor McGechan goes on teaching by his present method, he need not be afraid of the external examiner. It has been said that the external practitioner should not be a young man. That ought not to be so. I remember sitting examinations set by Mr. Justice Sim, Mr. Justice Alpers, Mr. Justice Ostler and Mr. Justice Kennedy; they may be the dull mediocrities of the past, but they were leaders in their day. I do not think the teachers have any reason to fear the effects of external examination."

\section{MR. W. P. SHORLAND (Wellington):}

"Regarding the length of the present solicitor's course, I offer no objection to it as a four-year course, but I do offer criticism of that course much along the lines indicated by Mr. Gresson, that only two years are devoted to the study of what we might call the practical law subjects. The other two years are devoted solely to the study of cultural or purely academic subjects. Bearing in mind the fact that the prescription of the examinations requisite for entrance to the legal profession is in the hands of the University, and that the prescription of those practical requirements for admission to law is also in the hands of the 
University, let us proceed from that to the University's reaction to the report of the special sub-committee of the Council of Legal Education that went fully into this matter in 1934. That Committee reported that qualitatively the old two-year course was all right, but that quantitatively it was too short, and the strongest recommendation it made was that one of the requisites for admission as a solicitor should be the furnishing of a certificate that the candidate had been engaged in actual practical work, either in a law office or in a Government Department handling legal work, for three years. For some reason or other, that recommendation was not adopted by the Council. My point is that, if the University is prepared to take the responsibility of making it possible for a student simply to pass the law course and then, without any practical experience or training in law, to go out and put up his name-plate and commence practice, then it is up to the University to prescribe a four-year course that will do more than the present course does to prepare a candidate for actual practice. I would say that rather than the cultural subjects, rather than even the academic subjects of Roman Law and Jurisprudence, which are essential for a solicitor, let the University devote the two years over and above the old professional course to class training, as being the next best thing to actual practical work. Let there be real training in conveyancing; there is some now, but my submission is that it does not go far enough. Let there be class training in the drawing of wills and company documents, and generally proper preparation for the man who is to be admitted, and let there be added to the syllabus some introduction to some of the statutes and regulations, matters which the practitioner is going to have to deal with the first day he goes into practice, but of which he has never heard at the University. Let him get acquainted with the Death Duties Act, and with some of the difficulties of section 9 of that Act; let him meet the Economic Stabilisation Regulations, and those practical things which he will have to face when he goes into practice. I say that that is more use to him than cultural subjects, or even Constitutional Law and Jurisprudence. I subscribe to the views put forward by Mr. Gresson. I add one point only: if Professor McGechan's proposals for examinations at each of the four Colleges being left in the hands of the professors were to eventuate, the inevitable result would be four different standards in New Zealand for admission to the law, and the consequence must be that one College would soon acquire a reputation for being an easy College for admission to the law, and we would have a state of affairs in which Colleges would be competing with one another for pride of place, or it may be for ease of entrance to the law. I think that that is aufficient reason in itself, apart from the very cogent reasons advanced by Mr. West and Mr. Gresson, for retaining the external examiner."

\section{MR. A. E. HURLEY (Wellington):}

"It seems to me that the discussion leaves us with no sense of complacency about the system of education, and I rather hoped that the discussion would not just end there I would move, 
That Professor McGechan's paper be referred to the New Zealand Law Society for consideration and such action as may be considered desirable."

The motion was seconded, and carried.

MR. L. P. LEARY (Auckland):

"One's mind has been so filled with new ideas this morning that it is a little difficult to encompass them. We are growing older, and it is a little hard to take in ideas even so comparatively revolutionary as Professor McGechan has put forward, or so completely revolutionary as Mr. Shorland has put forward. Personally, if I got him aright, I could not disagree more. It seems to me that to substitute for the teaching of Latin a knowledge of the Fair Rents Act, would be a very poor exchange. In a cultural profession such as ours, the two years are well employed in encompassing some cultural subjects, even although there may be some difference of opinion as to which are the right ones to read. I will leave that portion of the discussion, because it is possible that I am doing him an injustice, and he was putting a hypothetical case. With regard to Professor McGechan's view, I would like to say first that the strongest advocacy of those views was the clarity of their presentation and the reasonableness with which they were put, but it was indeed a very charming and convincing performance-if we were capable of being convinced. My difficulty is this: running through his thesis was the view that the external examiner is a mistake, and that the common examination paper lowers the standard. It may well be that we will come to that point of view some day; but I cannot absorb it just in a morning: I find great difficulty in appreciating that a carefully worded paper, based on the suggestions of the tutorial staff-and he was good enough to say that their suggestions were usually taken-can result in lowering the standard. I cannot help feeling that that procedure does obtain some uniformity; and uniformity, it seems to me, is desirable, because, as it was put by the previous speaker, there might grow up a reputation that one college was easier than another. The present system does not lay itself open to that evil, and, before we resign control of entrance to our profession wholly to the University, a good deal more propaganda for the provision will have to be made than the very able and eloquent speech we have heard this morning."

\section{PROFESSOR MCGECHAN:}

"There are one or two points on which I should touch in reply. First, about examining the sons of friends, fellow-members of the profession, and so on. I was a part-time teacher in Sydney, and I examined the sons of friends and legal clerks I knew, etc., without embarrassment. That may be a personal matter. I cannot see that a person who is trained in law, as we have been, cannot be fair to friends as well as others. The point was made that the profession had no say in the selection of teachers, but you know very well that committees deal with these matters, on which the profession is represented. When I was 
appointed, I was interviewed by several practitioners of this town. The profession has an indirect say in the appointment of teachers. As to the uniform standards that are necessary, I have suggested already that there is no uniform standard - at present. One College can get better results than another, and, if that is appreciated, a student could migrate from one centre to another because he could get better marks in one centre, or an easier pass. I know one or two students who have come to Victoria because they think they are getting better training there. I do not know of students travelling from one centre to another for other reasons. I do not think for a moment that, if there were four Colleges with four different standards, there would be many people who would migrate to go to an easier course. I think that some would travel to get a better course, and I think that that is desirable. The difficulty about uniform standards for entering a profession surely is magnified in New Zealand. In other places there are not uniform standards. For instance, in New South Wales, where I come from, they either pass a University examination or a Bar examination, and both are acceptable. Moreover, people were admitted from New South Wales, Queensland, and South Australia, and were all practising in one Court, and I think the Court benefited from that variety. I think the New Zealand Courts would benefit from a variety of training of its practitioners. We talk too much about uniformity. I repeat the statement that at present we have mediocrity. It is mediocre training I am driving at, not mediocre men. What we want is a healthy variety. My own hope is that we will have four examinations within a reasonable time, and then you will have to face the problem of four different standards."

\section{Mr J GRAHAM (Feilding):}

"The resolution carried by the Conference just before lunch referred to the New Zealand Law Society "taking action." That might indicate that this Conference, without any qualification, approved of the paper. With the permission of the Conference, and subject to your ruling, I should like to move the following motion:

That the paper referred to in the previous resolution does not necessarily represent the views of the Conference, but that the paper was discussed, and views were expressed on both sides."

MR. A. E. LAWRY (Napier) seconded the motion.

MR. A. E. HURLEY "My resolution made that clear, I think."

The Chairman ruled that Mr. Graham's motion was in order.

The motion was carried. 
(1999) 30 VUWLR 